\title{
EDITORIAL
}

\section{International Lawyers as Public Intellectuals and the Need for More Books}

\author{
CECILY ROSE*
}

\section{INTRODUCTION}

In the summer of 2014 I attended a conference panel on international lawyers as public intellectuals. ${ }^{\mathrm{I}}$ The academics on the panel talked about their twitter accounts, their blogs, their occasional radio and television appearances, and their opinioneditorials in major newspapers. The discussion really focused not on whether international lawyers should be public intellectuals, but on how they can do so, and what the ramifications of such public engagement can be. What struck me most, however, was a notable omission: no one on the panel or in the audience mentioned books as a medium through which public international lawyers might reach a mass audience. In reflecting on this omission I realized that academics in this field do not, for the most part, write books for a general readership. To the extent that public international lawyers reach a mass audience at all, they have chosen do so through other means - with some exceptions.

At the outset, two points bear mentioning. First, in my view international lawyers shouldact as public intellectuals. Second, there are some rare and important examples of international law books written for a general audience, which must be noted. On the first point, I regard international legal academics as having a professional duty to explain how international law relates to current world affairs as well as historical events. Every week, if not every day, newspapers run stories that have great relevance for the international legal field. The views of international lawyers certainly inform these articles, as international legal academics field phone calls from reporters in need of an expert opinion or a nice quotation. But international lawyers ought to reach a general audience in their own words, if only for the sake of thoroughness and accuracy (we have all undoubtedly read newspaper articles that failed to identify, or misidentified, the relevant international court or tribunal in The Hague). International lawyers have an important role to play in explaining what

* Senior editor, Leiden Journal of International Law; assistant professor, Grotius Centre for International Legal Studies, Leiden University [c.e.rose@law.leidenuniv.nl]. Many thanks to Niels Blokker, Erik Koppe, Jonathan Rose, and Larissa van den Herik for their comments on an earlier draft of this piece.

I Australia New Zealand Society of International Law 22nd Annual Conference, July 2014, Panel Discussion on International Lawyers as Public Intellectuals. The chair was Madelaine Chiam and the panelists were Hilary Charlesworth, Ben Saul, Dino Kritsiotis, and Sarah Joseph. 
international law is, how it works, and what role it plays in settling international disputes or framing negotiations. As experts in a field with great practical relevance, international lawyers are in a strong position to help frame and inform the public debate, especially as compared with journalists.

Furthermore, international legal academics do not diminish their status as scholars by acting as public intellectuals - a view that I have heard repeatedly in certain ivory towers. Sharing knowledge at a basic or introductory level does not lessen the scholarly accomplishments of international legal academics. Whether academics share their knowledge through lectures for undergraduates or books for a general audience, this sort of introductory-level teaching is a legitimate function of being a scholar. Moreover, the ability to explain international law to non-lawyers requires real skill that reflects scholarly ability and years of teaching experience. Writing books for a lay audience undoubtedly takes time away from scholarly research, but the same can be said of the work that many international legal academics do as practitioners in the field. The ability to explain complex ideas to a non-expert audience is a function of being an academic and teacher, not a sign that one has stepped outside of the role of the scholar.

Second, it would be unfair to claim that international legal academics have entirely failed to produce books for a general audience. Philippe Sands, for example, has written two books on how the Bush Administration violated international law through its invasion of Iraq and its interrogation policies (Lawless World (Allen Lane, 2005) and Torture Team (Palgrave Macmillan, 2008)). In addition, Samantha Power's 'A Problem from Hell': America and the Age of Genocide (Basic Books, 2002) is a Pulitzer Prize-winning history of the development of genocide as a legal concept, and the United States' repeated failure to act in the face of genocide. Power's book is a particularly good example of accessible writing about the law. She manages to discuss the Genocide Convention's definition of genocide, for instance, without using a great deal of technical vocabulary, and while providing much historical context, which makes this Convention's entry into force rather suspenseful. ${ }^{2}$

The examples, of course, go beyond the United States' troubled relationship with international law. In War Law (Atlantic Books, 2005), for example, Michael Byers wrote about various aspects of the law on the use force, as well as the law of armed conflict. Furthermore, Michael Matheson explored the UN Security Council's expansive exercise of legal authority since the end of the Cold War in Council Unbound (United States Institute of Peace Press, 2006). In the areas of refugee law and human rights law, Jane McAdam and Fiona Chong have published Refugees: Why Seeking Asylum is Legal and Australia's Policies Are Not (University of New South Wales Press, 20I4), while Eric Posner has published The Twilight of Human Rights Law (Oxford University Press, 20I4). In addition, books for lay readers in other languages should also be mentioned, such as Emmanuelle Tourme-Jouannet's Le droit international (Presses Universitaires de France, 2013).

2 S. Power, "A Problem from Hell”: America and the Age of Genocide (2003), 65-70. 
The work of the international criminal courts and tribunals in The Hague has arguably generated the most substantial body of books for lay readers, with books like Unimaginable Atrocities: Justice, Politics, and Rights at the War Crimes Tribunals by William Schabas (Oxford University Press, 20I4), Crimes Against Humanity by Geoffrey Robertson (New Press, 2013) and Srebrenica: Record of a War Crime by Jan Willem Honig and Norbert Both (Penguin, I997). This corner of the international legal field appears to have given rise to a disproportionate number of books for lay readers.

As these examples show, the international legal field does not completely lack books for a general audience. But such books are still very much the exception, and they do not seem to become bestsellers. In light of the fact that international legal issues appear in the news on a daily basis, and international law addresses an ever-expanding list of global problems, we might expect to see a more robust body of books for a general audience, on a broader range of topics. We might expect, for example, to see books about how international law relates to climate change, investor protection, and the South China Sea. The media covers these topics on a weekly, if not daily, basis, and yet we lack books by international lawyers that could provide the public with much needed explanations about how international law relates to these transnational issues. Books for a general audience are, however, few and far between. In general it is fair to say that international lawyers produce books for a general audience on an exceptional basis, and to a far lesser extent than academics in other university departments.

\section{THE STANDARD EXPLANATIONS FOR THE PAUCITY OF BOOKS FOR A GENERAL AUDIENCE}

When I have remarked on the lack of international law books for a general audience in conversation with friends and colleagues, I have generally heard two explanations. The first is that books for a mass audience do not count as academic publications. In light of the fact that law faculties generally expect their staff to produce a certain number of academic publications every year, writing such books represents an especially time-consuming diversion, which attracts no formal credit. In other words, most of us just cannot afford to spend our time this way. Second, another common explanation is that international law is too technical and difficult to explain to a mass audience. Such books either would not have an audience, or they would lose their audience as soon as they entered into technical discussions of legal rules and their application. According to this explanation, we lack a real market for such books.

These explanations make sense, until one looks outside of the international legal field, to domestic legal fields, the social sciences, and even the hard sciences. Books by academic historians, for example, appear nearly every year on The New York Times' list of the ten best books of the year, a list compiled by the editors of The New York Times Book Review. This list, which can arguably be taken as a proxy for excellent books for a general audience, has yet to include an international law book. The New York Times' regular inclusion of history books written by academics on this list raises 
important questions about what incentivizes historians to write these books, and whether they are valued within the discipline. These are questions worth pursuing in future research and thinking on this issue.

The paucity of international law books written for a general audience forms an especially stark contrast with the field of economics. In economics faculties, prominent academics have shared their research with a general audience by writing books that have become bestsellers. While this may not be routine, it is also not rare or unheard of. Thomas Piketty's recent Capital in the Twenty-First Century (Belknap Press, 20I4) is a particularly good example, as it has helped to shape public debate on the unequal distribution of wealth in developed countries. In addition, Jeffrey Sachs and William Easterly brought their intellectual debate about the effectiveness of development aid into the open by publishing dueling books on the subject in the mid-200os (Jeffrey Sachs, The End of Poverty (Penguin Books, 2005) and William Easterly, The White Man's Burden (Penguin Books, 2006)). More recently, Abhijit Banerjee and Esther Duflo have brought a different perspective to the same subject, with their book Poor Economics (PublicAffairs, 20I I). Yet another prominent example is Robert Shiller's Irrational Exuberance (Princeton University Press, 2000), which analyses the US stock market bubble. In 20I3 Shiller received a Nobel Prize for his empirical research on asset prices, along with Eugene F. Fama and Lars Peter Hansen. Leading economists have also written books about financial crises, including Carmen Reinhart and Kenneth Rogoff's This Time is Different (Princeton University Press, 2009), and Paul Krugman's The Return of Depression Economics and the Crisis of 2008 (W. W. Norton, 2008). Nearly all of these books have been New York Times bestsellers. Compared to public international law, the field of economics is replete with examples of prominent books for a general audience.

The fact that economists author books for a general audience with some frequency raises questions about why international legal academics are not doing the same. Academic economists also face requirements regarding their publication records, and books for a general readership are of no help in this regard. Perhaps for this reason, many of the popular economics books have been written by tenured faculty members, who may no longer be as concerned about 'publishing or perishing'. Likewise, economics is also a technical field, to a greater extent than international law, I would argue. Because many non-economists simply lack training in econometrics or statistics, this creates a serious hurdle for economists attempting to reach a general audience. This may also, in turn, create a greater need for economists to write books for lay readers, as economics can be somewhat counterintuitive and is generally less accessible than the law; misunderstandings and conspiracy theories abound. The point remains that economists manage to overcome this gap in knowledge by explaining their terminology and simplifying their analysis. The standard explanations as to why international lawyers do not write books for a general audience leave me unconvinced.

I also doubt these standard explanations because legal academics and judges in domestic law fields do, in fact, write books for a lay audience. If domestic lawyers can explain their research to non-lawyers, then international lawyers can do the same. Richard Posner is a prominent example. As a US Federal Appeals Court Judge, senior 
lecturer at the University of Chicago, and leader in the field of law and economics, Posner is a particularly prolific author of books for a general audience about domestic law and related topics (including the decline of the public intellectual in American life). Tom Bingham, a British Law Lord, was another judge who wrote for a general audience, with his book on The Rule of Law (Penguin, 20I I). Within academia itself, Cass Sunstein (of Harvard Law School) and Bruce Ackerman (of Yale Law School) are two particularly leading examples, as both have written book after book for lay readers. In addition, a number of leading domestic legal scholars have written books on the rights of American citizens, as a part of the Inalienable Rights series published by Oxford University Press. ${ }^{3}$ The examples do go beyond Anglo-American judges and scholars, although more extensive research would be needed in order to determine whether law books for lay readers are primarily an American phenomenon. For the German market, for instance, Uwe Wesel (of the Free University of Berlin) published Fast alles, was Recht ist: Jura für Nicht-Juristen (2007), which introduces lay readers to legal reasoning and legal language, as well as different areas of the law.

While the two standard explanations lose their force as soon as we look beyond the international legal field, there also do not seem to be any obvious alternative answers. One possibility could be that publishers are playing an unseen role in squelching international law books for a general audience. But without evidence that publishers are reluctant to publish such books, this remains purely speculative. Another possibility might be that prominent international legal academics tend to become more immersed in practice, the more senior they become, thereby eliminating any spare time that they might have otherwise had to write books for a general audience. In addition, international legal practice may be more lucrative than a bestselling international law book. Yet, some still manage to write these books while engaged in practice. Moreover, prominent economists also produce books while engaged in other non-academic activities, such as providing expert witness testimony. On the whole, however, economists may have fewer opportunities than lawyers to become engaged in practical work.

Alternatively, perhaps the international legal field just lacks sufficient examples of bestselling or even just widely read international law books that have helped to shape public debate. The status quo could be viewed as discouraging, and it may do little to inspire more books of this genre. In other words, international lawyers attempt books for a lay audience relatively rarely, and generally have not had enormous success when they have done so, thus not inspiring a great number of books for lay readers. On the whole, the trend is less than impressive, and this may be self-perpetuating.

Finally, could it be that international lawyers simply lack a demand for such books? This, of course, remains a possibility, but in my view an unlikely one.

3 The authors are Martha C. Nussbaum, Alan M. Dershowitz, Christopher H. Schroeder, Richard A. Posner, Mark V. Tushnet, Richard A. Epstein, Laurence H. Tribe, David A. Strauss, Eric Posner, Michael J. Klarman, and Lee C. Bollinger. Oxford University Press USA, Inalienable Rights, <https://global.oup.com/ academic/content/series/i/inalienable-rights-ir/?cc $=$ nl\&\&facet_narrowbytype_facet $=$ General+Interest \& $\mathrm{cc}=$ nl\&lang $=\mathrm{en}>($ accessed I May 20I5). 
International law relates closely to some of the most pressing issues of our time, from terrorism to climate change. My assumption is that the prominence of these issues, which generate intense news coverage, must be matched by some demand for sustained, book-length discussions by experts in the international legal field. This has proven to be true in the field of economics, where economists write bestselling books about income inequality, development aid, stock prices, and financial crises, for example. There is no apparent reason why a similar demand would not exist for books by international lawyers.

\section{The STEADY SUPPLY OF INTERNATIONAL LAW BOOKS FOR AN EXPERT AUDIENCE}

While international law books for a general audience remain rare, international lawyers seem to be publishing books for an expert audience with impressive frequency. Taken together, Cambridge University Press and Oxford University Press alone publish well over one hundred international law monographs every year. Unlike in many other disciplines, most $\mathrm{PhD}$ researchers in this field tend to write their dissertations with a view towards future publication in the form of a book, rather than a series of separate articles. Many academics in the field will never publish another monograph, as peer-reviewed journal articles are the primary method for disseminating research. But it would not be entirely out of the ordinary for an international legal academic to publish another monograph mid- or late-career. Moreover, American international legal academics who publish books generally do so only later in their careers, as they typically do not write $\mathrm{PhDs}$ in law that can later be turned into books. By contrast, in other fields such as economics, peer-reviewed articles are the primary means for publishing the results of research, both at the beginning and throughout their academic careers.

The role of books as an integral part of international legal scholarship seems to contribute to the field's overall inaccessibility. These monographs are not only inaccessible to a lay audience in terms of their substance, but they are also very costly for many international lawyers themselves. ${ }^{4}$ Oxford University Press and Cambridge University Press, for example, sell monographs as hardbacks, at least initially, and they typically cost between $€ 70$ and $£$ I25. The cost of books in this field can be a deterrent for junior academics who might like to own books of particular interest. Libraries are really the intended purchasers of these books, and that is where many have to turn in order find copies.

This is not to question why publishers have priced these books the way they have. My only purpose here is to observe that the cost of monographs has consequences for the effectiveness with which international lawyers are disseminating their knowledge and research, even within the field. International lawyers are not writing books for a general audience (with some exceptions), and the books that they do write are for an expert audience that often cannot afford to purchase them (though their

4 F. Baetens and V. Prislan, 'Editorial: The Dissemination of International Scholarship: The Future of Books and Book Reviews', (20I4) 27 LJIL 559. 
libraries hopefully can). Finally, open access publishing policies do not yet enter into this equation in a significant way. ${ }^{5}$ Universities in the United Kingdom, for example, now require open access publishing for peer-reviewed articles and conference proceedings, but these policies do not apply to books. ${ }^{6}$ Moreover, academic publishers have only just begun to experiment with open access monographs and the future of this is uncertain. ${ }^{7}$

\section{THE BenEFITS OF BOOKS}

Books have some important advantages in comparison with the other means for reaching a mass audience, namely blogs, newspaper articles, radio and television appearances, the UN's Audiovisual Library of International Law, and massive open online courses. ${ }^{8}$ First, books allow international legal academics to present their research and opinions on their own terms, not just in response to a question posed by a journalist or reporter. Writing books allows international lawyers to have time to reflect, and to do their own framing - to do more than just react to a current event. This is particularly important if international lawyers are not only going to explain how international law relates to current events, but also present their own scholarly research to the general public. Second, the sheer length of books makes them a better format for a sustained exploration of a given subject. Blog posts and newspaper articles are simply not comparable to a book-length discussion of international law, which will be broader and in greater depth. Blog posts and newspaper articles can only provide a sketch, while books can provide a full depiction.

Books for lay readers also have an advantage in relation to publications for an expert audience. Not all of the knowledge that international lawyers accumulate in their research and practice will always be appropriate for publication in journal articles or monographs for an expert audience. Anecdotal information may, for example, be better suited to books geared towards a general audience, which benefit from narrative storytelling.

Massive open online courses (MOOCs) may be the most relevant comparator for our purposes. MOOCs are a relatively recent phenomenon, which international lawyers appear to have embraced..$^{9}$ MOOCs are online courses designed for a mass audience of thousands, or tens of thousands. The participants are not only university students, but also members of the general public. MOOCs involve video lectures, reading assignments, and assessments through, for example, quizzes and a final exam. The end result is a certificate of successful completion, rather than credits

5 Ibid., 562.

6 Higher Education Funding Council for England, Open Access Research, <http://www.hefce.ac.uk/ rsrch/oa/monographs/> (accessed I May 2015).

7 Oxford University Press, e.g., has recently published a small number of international law monographs through Open Access Publishing in European Networks (OAPEN) as part of a pilot program. OAPENUK, The Pilot, <http://www.hefce.ac.uk/rsrch/oa/monographs/> (accessed I May 20 I5). See H. E. Kjos, Applicable Law in Investor State Arbitration (2013); K. J. Heller and G. Simpson, The Hidden Histories of War Crimes Trials (2013); $\mathrm{S}$. Joseph, Blame it on the WTO? A Human Rights Critique (2013).

8 See Baetens and Prislan, supra note 4, 560-6I.

9 L. Pappano, 'The Year of the MOOC', The New York Times (2 November 201 2). 
that go towards the completion of a university degree, although this may change in the future. The UN's Audiovisual Library of International Law arguably plays a similar role, in that the videos by international legal experts are designed for 'an unlimited number of recipients around the world'. ${ }^{\text {Io }}$ But these videos are usually under an hour long, and therefore cannot convey the same breadth or depth of information as a MOOC or a book.

In light of the fact that MOOCs only really emerged as a popular form of online learning in 20I2, international lawyers have moved quite quickly in embracing this medium. Christian Tams, Robin Geiss, and Antonios Tzanakopoulos (University of Glasgow); Michael Scharf(Case Western Reserve University); Laurence Helfer (Duke University); Olivier de Schutter (University of Louvain); Pierre d'Argent (University of Louvain); Maya Hertig Randall, and Michel Hottelier (University of Geneva) have all produced MOOCs on international law since the emergence of this form of online education. II At the time of this writing, I am also in the midst of making a MOOC, along with Larissa van den Herik and Yannick Radi, on Global Justice in Action: A Guide to the International Courts and Tribunals in The Hague.

While the material that can be covered in a MOOC on international law will be more extensive than that covered in a blog post or opinion editorial piece, it will usually still be less than what a book would be able to canvass. MOOCs typically contain about six to eight hour-long videos, spread over the same number of weeks. In addition, MOOCs tend to resemble survey courses, which introduce a broad subject, while books for a general audience often focus more specifically on a given topic. Ideally MOOCs would complement existing books for a mass audience, as video lectures and written materials are quite different ways of presenting information to a general audience. But instead it seems that international lawyers may have somewhat overlooked books, in favour of MOOCs.

The embrace of MOOCs by international lawyers does show, however, that international law can indeed be explained to a lay audience. MOOCs therefore chip away at one of the standard explanations as to why international lawyers do not write books for a general audience. If technical legal rules and arguments can be explained in a video lecture, then why not in a book?

Io United Nations, Audiovisual Library of International Law, Background, <http://www.un.org/law/avl/>; accessed I May 2015.

I I C. Tams, 'World War I: Paris I9I9 - A New World Order?' <https://www.futurelearn.com/ courses/wwI-new-world-order> (accessed I May 20I5); C. Tams, R. Geiss, and A. Tzanakopoulos, 'Right vs Might in International Relations', <https:/www.futurelearn.com/courses/right-vs-might>; accessed I May 20I5; M. Scharf, 'Introduction to International Criminal Law', <https://www.coursera. org/course/intlcriminallaw>; accessed I May 20I5; L. Helfer, 'International Human Rights Law: Prospects and Challenges', <https://www.class-central.com/mooc/I77I/coursera-international-humanrights-law-prospects-and-challenges >; accessed I May 2015; O. de Schutter, 'International Human Rights', <https://www.edx.org/course/international-human-rights-louvainx-louv2x\#.VP82gmjF_QI>) (accessed I May 20I5); P. d'Argent, 'International Law', <https://www.edx.org/course/internationallaw-louvainx-louv5x\#.VP83mmjF_QI> (accessed I May 20I5); M. Hertig Randall, M. Hottelier, Z. Kibboua, and A. Vallelian, 'Introduction aux droits de l'homme' < https://www.coursera.org/course/droitshomme> (accessed I May 2015). 


\section{Conclusion}

Even though international lawyers as a whole already seem to produce an abundant amount of writing, this editorial is nevertheless calling for more. In light of the fact that we already have more than enough blogs, specialized journals, edited volumes, and books for an expert audience, why would more books be a good idea? This editorial's call for more might therefore strike some as potentially contributing to an existing problem of oversaturation. But these books would reach a different, lay audience, which is currently underserved. While one would hope that international lawyers would be among the readership of these books, they would not necessarily be the primary intended audience.

As it stands, international lawyers are not doing enough to explain how international law relates to world affairs, both past and present. They are not doing enough to make their scholarly research accessible to the general public as a matter of substance. Looking outside of the discipline brings this situation into relief. Leading economists write books for a general audience with some regularity, and in doing so they enable their research to influence public debate. What holds international lawyers back remains somewhat unclear, but the reasons for acting are manifest. 